\title{
Release of Indigenous Gases from LWR Fuel and the Reaction Kinetics with Zircaloy Cladding
}

by
C. E. Beyer

C. R. Hann

April 1977

Prepared for Core Performance Branch Nuclear Regulatory Commission 


\section{DISCLAIMER}

This report was prepared as an account of work sponsored by an agency of the United States Government. Neither the United States Government nor any agency Thereof, nor any of their employees, makes any warranty, express or implied, or assumes any legal liability or responsibility for the accuracy, completeness, or usefulness of any information, apparatus, product, or process disclosed, or represents that its use would not infringe privately owned rights. Reference herein to any specific commercial product, process, or service by trade name, trademark, manufacturer, or otherwise does not necessarily constitute or imply its endorsement, recommendation, or favoring by the United States Government or any agency thereof. The views and opinions of authors expressed herein do not necessarily state or reflect those of the United States Government or any agency thereof. 


\section{DISCLAIMER}

Portions of this document may be illegible in electronic image products. Images are produced from the best available original document. 


\title{
NOTICE
}

This report was prepared as an account of work sponsored by the United States Government. Neither the United States nor the United States Nuclear Regulatory Commission, nor any of their employees, nor any of their contractors, subcontractors, or their employees, makes any warranty, express or implied, or assumes any legal lability or responsibility for the accuracy, completeness or usefuhess of any iniormation, apparatus, product or process disclosed, or represents that its use would not iniringe privately owned rights.

\section{PACIFIC NORTHWEST LABORATORY}

operated by

BATTELLE

for the

ENERGY RESEARCH AND DEVELORMENT ADMINISTRATION

Under Contract EY-76-C-06-1830

\author{
Printed in the United States of America \\ Avaliable from \\ Natuonal Technical Information Service \\ U.S. Department of Commerce \\ 3285 Pont Royal Road \\ Springivield, Virginia 2215
}

Price: Printed Cooy \$___." Microfiche $\$ 3.00$

\begin{tabular}{|c|c|}
\hline Pages & $\begin{array}{c}\text { NTIS } \\
\text { Selling Price }\end{array}$ \\
\hline $00 \%-025$ & $\$ 4,50$ \\
\hline 026.050 & $\$ 5.00$ \\
\hline $059-075$ & $\$ 5.50$ \\
\hline $0 \div 5-100$ & $\$ 6.00$ \\
\hline $107-125$ & $\$ 6.50$ \\
\hline $1260-150$ & 57.00 \\
\hline $151-179$ & $\$ 7.75$ \\
\hline $176-200$ & $\$ 8.50$ \\
\hline $201-225$ & $\$ 8.73$ \\
\hline 216.250 & $\$ 9.00$ \\
\hline $251-275$ & $\$ 10.60$ \\
\hline $276-300$ & $\$ 70.35$ \\
\hline
\end{tabular}


BNWL -1956

NRC 1 and 3

RELEASE OF INDIGENOUS GASES FROM LWR FUEL

AND THE REACTION KINETICS WITH ZIRCALOY CLADDING

by

C. E. Beyer

C. R. Hann

April 1977

Prepared for Core Performance Branch

Nuclear Regulatory Commission

Thes seport was propice

sponsored by the prepared as an account of work

the Uhated States nor the Unted Sungent heather

Research and Development Admumsto states Inergy

dear employees, nor any of therr, hor any of

warrantry tors, of therr employees, snates ans,

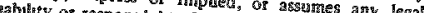

or usefulnes of any ny for the accuracy, completeress

proesss duectoed or son

infunge provately, owmed nghts

BATTELLE

PACIFIC NORTHWEST LABORATORIES

RICHLAND, WASHINGTON 99352 



\section{ACKNOWLEDGMENTS}

The authors appreciate the support of the Core Performance Branch, Nuclear Regulatory Commission and the comments of R. Lobel during the review of this report. 


\section{CONTENTS}

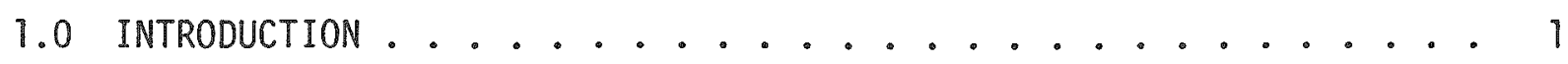

2.0 RELEASE RATE OF GASEOUS IMPURITIES ............ 4

3.0 AMOUNT AND COMPOSITION OF GASEOUS IMPURITIES RELEASED .... 5

4.0 GASEOUS IMPURITIES - ZIRCALOY CLAD REACTION KINETICS ...... 11

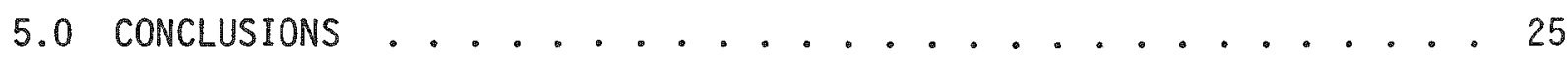

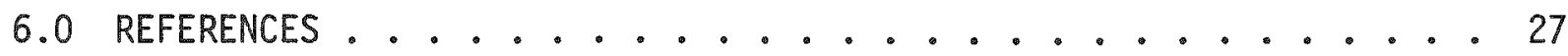
DISTRIBUTION ..................................... 


\section{RELEASE OF INDIGENOUS GASES FROM LWR FUEL AND THE REACTION KINETICS WITH ZIRCALOY CLADDING}

by

C. E. Beyer and C. R. Hann

\subsection{INTRODUCTION}

The release and disposition of gaseous impurities within an oxide fuel rod can affect internal rod pressures and fuel-to-cladding gap conductance, and consequently fuel temperatures.

Past experimental evidence ${ }^{(1)}$ from fuel rods with pressure sensors has indicated that rod internal pressures decrease after the initial startup and then increase after a few days due to the release of fission gases. These observations have led to speculation that gaseous impurities released during startup are reacting with the cladding during the first few days of operation. If significant amounts of indigenous gases (in comparison to the amount of fill gas) are released during startup, it becomes necessary to model this phenomena for fuel performance calculations. (2) The amount of gas released at any point in time is needed to calculate internal rod pressure, and the gas composition is needed to calculate gas conductivity and thus the gap conductance.

To illustrate the effects of indigenous gas release within a typical LWR fuel rod we have utilized the GAPCON-THERMAL-2 fuel performance code. This code models the reaction of the gases with the clad and assumes immediate release of the gas at power, based on the results of this study. The effects of releasing $0.026 \mathrm{~cm}^{3} / g$ of nitrogen ${ }^{(a)}$ are compared against 0 release

(a) This is a realistic amount for nitrogen and carbon monoxide releases from $\mathrm{UO}_{2}$ fuel sintered in cracked ammonia and $\mathrm{U}_{2}-\mathrm{PuO}_{2}$ sintered in a $\mathrm{Ar}-\mathrm{H}_{2}$ mixture, respectively (keeping in mind there is a large degree of uncertainty in these releases). However, $\mathrm{UO}_{2}$ fuel sintered in hydrogen releases a much smaller amount of these two gases $\left(-0.005 \mathrm{~cm}^{3} / \mathrm{c}\right)$. 


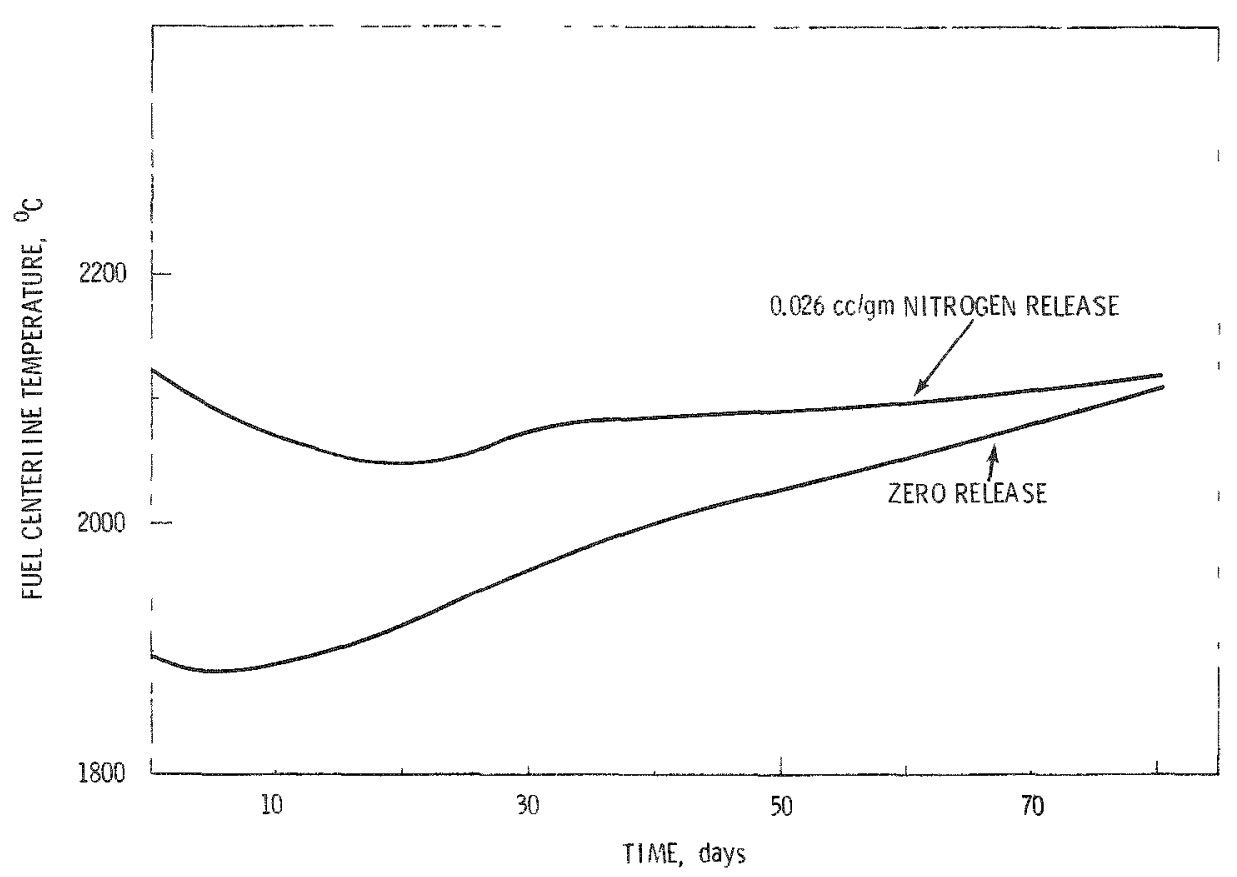

FIGURE 1a. Effect of $0.026 \mathrm{~cm}^{3} / \mathrm{g}$ Nitrogen Release on Fuel Centerline Temperature for a BWR-6 Rod at $14.0 \mathrm{~kW} / \mathrm{ft}$ (using GAPCONTHERMAL-2)

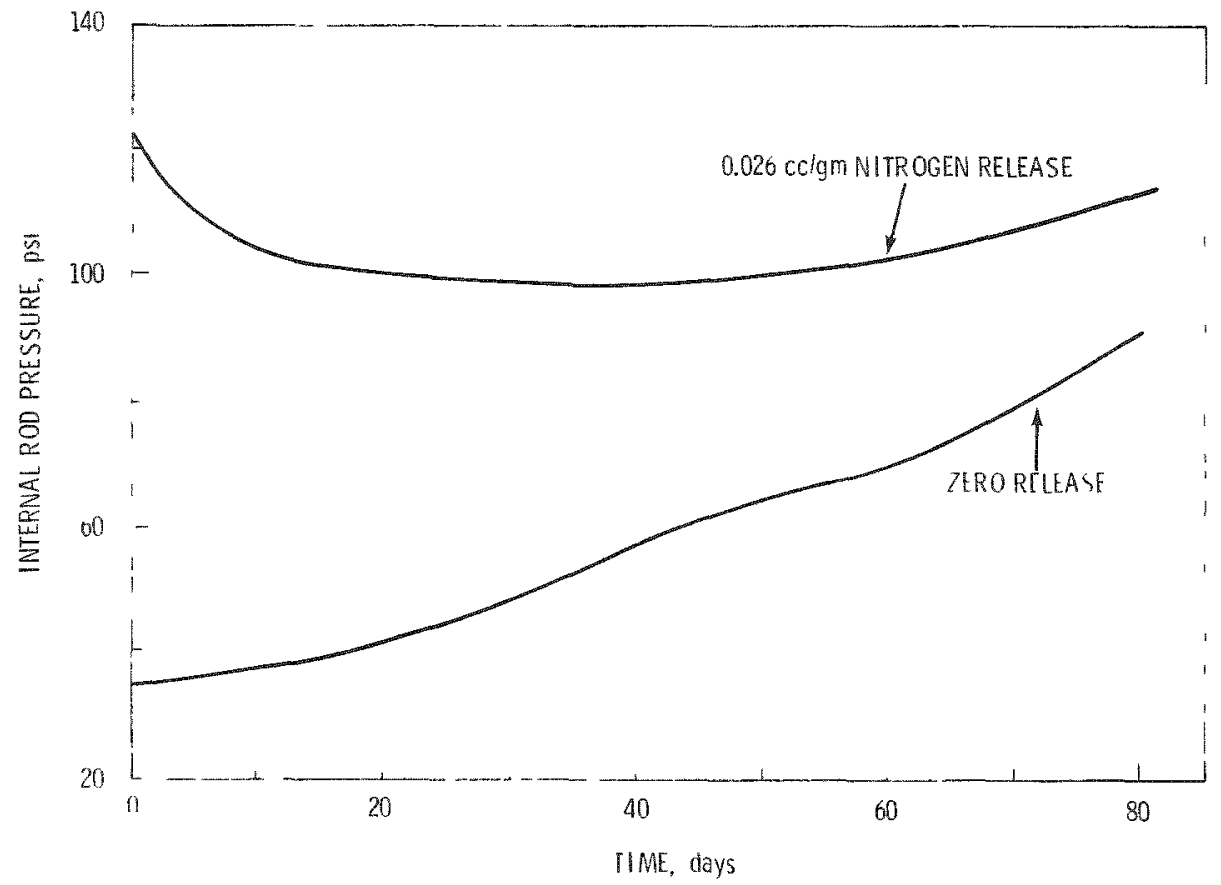

FIGURE 1D. Effect of $0.026 \mathrm{~cm}^{3} / \mathrm{g}$ Nitrogen Release on Internal Rod Pressures for a BWR-6 Fuel Rod at $14.0 \mathrm{~kW} / \mathrm{ft}$ (using GAPCON-THERMAL-2) 
(Figures $1 \mathrm{a}$ and $1 \mathrm{~b}$ ) for a $B \mathrm{WR}-6$ fuel rod at $14.0 \mathrm{~kW} / \mathrm{ft}$. The fuel centerline temperature and internal rod pressure are $.200^{\circ} \mathrm{C}$ and $90 \mathrm{psi}$ higher for 0.026 $\mathrm{cm}^{3} / \mathrm{g}$ nitrogen release. These differences are shown to decrease with in-reactor time and become negligible after 280 days. This is the result of the nitrogen being consumed by reaction with the clad. A similar calculation using $0.026 \mathrm{~cm}^{3} / \mathrm{g}$ of carbon monoxide has shown similar results at beginning of life with the differences between $0.026 \mathrm{~cm}^{3} / \mathrm{g}$ and 0 release negligible after 20 days. The effect typical hydrogen, moisture, and oxygen releases have on gap conductance and internal pressure are negligible for all practical purposes (as will be shown in Section 3.0) because of their relatively fast reaction kinetics with the cladding and/or fuel.

The relative effects of releasing similar amounts of nitrogen and carbon monoxide in a PWR fuel rod is much smaller. A GAPCON-THERMAL-2 calculation comparing $0.026 \mathrm{~cm}^{3} / \mathrm{g}$ and 0 nitrogen release has only shown a $32^{\circ} \mathrm{C}$ increase in centerline temperature and a $13 \%$ increase in rod pressures at beginning of life.

The objective of this study was to evaluate the open Titerature data to estimate:

- the rate of gaseous impurity release from oxide fuel,

- the amount and composition of the gaseous impurities,

- their subsequent rate of reaction with the fuel or Zircaloy. 


\subsection{RELEASE RATE OF GASEOUS IMPURITIES}

Spalaris and Magerth ${ }^{(4)}$ found the release of gaseous impurities from $\mathrm{UO}_{2}$ pellets to be very rapid with nearly a 71 of the total gas release occurring during the first 7 min of outgassing at temperatures of 1500 and $1700^{\circ} \mathrm{C}$. Lower temperature $\left(1400^{\circ} \mathrm{C}\right)$ tests by the same investigators released only $u / / 5$ of the total gas held within the $\mathrm{UO}_{2}$ pellets; however, the tests exhibited the same initial release kinetics with the release rate approaching zero after 25 min at temperature.

Wheeler ${ }^{(5)}$ has performed diffusion experiments with $\mathrm{UO}_{2}$ single crystals and showed that the fraction of hydrogen released approached $100 \%$ release within $450 \mathrm{sec}$ at $1000^{\circ} \mathrm{C}$ and within $2250 \mathrm{sec}$ at $800^{\circ} \mathrm{C}$. Although the release rates for the other gases are slower, rates can be considered relatively fast in terms of total irradiation time.

Denovan et a1. (6) have indicated that a temperature of $1000^{\circ} \mathrm{C}$ is needed to extract all of the gaseous impurities in a reasonable amount of time $(1 / 2$ to $2 \mathrm{hr})$. The lack of release rate data for a broad range of temperatures precludes the development of a quantitative release model; however, from the above information we can come to some tentative conclusions about the release of adsorbed gases in axide fuel:

- Nearly $100 \%$ of the gases are released above $1000^{\circ} \mathrm{C}$ and approximately $20 \%$ at $400^{\circ} \mathrm{C}$.

- The release kinetics are very rapid, a matter of minutes, for temperatures $\geq 1000^{\circ} \mathrm{C}$.

0xide fuel rods operating at $15 \mathrm{~kW} / \mathrm{ft}$ with a fuel surface temperature of $600^{\circ} \mathrm{C}$ will have $\sim 70 \%$ of the fuel above $1000^{\circ} \mathrm{C}$ so that somewhere between 80 to $100 \%$ of the gaseous impurities will be released. In comparison, fuel rods operating at $11 \mathrm{~kW} / \mathrm{ft}$ and a surface temperature of $500^{\circ} \mathrm{C}$ wi 11 have only $45 \%$ of the fuel above $1000^{\circ} \mathrm{C}$ with somewhere between 60 to $100 \%$ of the gaseous impurities released. Because the available data do not provide the means for a more quantitative estimate of the fractional release of adsorbed gases from operating fuel, we have assumed that $100 \%$ of the gases are released. Additional data are needed for fuel temperatures between 400 and $1000^{\circ} \mathrm{C}$ wherein release fractions appear to vary from 20 to $100 \%$. 


\subsection{AMOUNT AND COMPOSITION OF GASEOUS IMPURITIES RELEASED}

Five reports $(4,6-9)$ supply data on the amount and composition of gaseous impurities released from oxide fuel pellets determined from outof-reactor heating (outgassing) tests. Such tests are performed by heating the pellet(s) in a vacuum and measuring the amount of gas evolved within a known volume, then analyzing the composition with a mass spectrometer. Table 1 lists the reports, and summarizes the data and material property information.

Inspection of the five parameters listed below and the data in Table 1 indicates that these parameters have a significant influence on the amount and/or the composition of the gases released:

- fuel type, $\mathrm{UO}_{2}$ or $\mathrm{UO}_{2}-\mathrm{PuO}_{2}$

- pellet density

- sintering atmosphere

- storage atmosphere

- vacuum outgassing

The oxide fuels, $\mathrm{UO}_{2}$ and $\mathrm{UO}_{2}-\mathrm{PuO}_{2}$, are presently the only fuels being used in light water reactors (LWRs). The mixed oxide data in Table 1 is of the LMFBR composition $75 \% \mathrm{UO}_{2}-25 \% \mathrm{PuO}_{2}$ instead of the 1 to $5 \% \mathrm{PuO}_{2}$ contemplated for use in LWRs; however, the fabrication steps for both mixed oxide fuels are similar. No outgassing data were found to exist for mixed oxide fuel with the proposed LWR compositions.

A comparison of the two fuel types $\left(\mathrm{UO}_{2}\right.$ and mixed oxide) shows the compositions of gaseous impurities released to be significantly different under specific conditions.

The $\mathrm{UO}_{2}$ sintered in hydrogen releases primarily hydrogen $(275 \%)$ with minor amounts of carbon monoxide, carbon dioxide and nitrogen. Denovan et a1. (6) concluded that the majority of hydrogen comes from adsorbed moisture rather than from the hydrogen sintering atmosphere. They sintered both natural and enriched $\mathrm{UO}_{2}$ in a deuterium atmosphere and analyzed them for deuterium and hydrogen by vacuum outgassing. These outgassings showed 


\begin{tabular}{|c|c|c|c|c|c|c|c|c|c|c|c|c|c|c|}
\hline \multirow[b]{2}{*}{ REFERENCE } & \multirow{2}{*}{$\begin{array}{c}\text { NUMBER OF SAMPLES } \\
\text { OUTGASSED } \\
\end{array}$} & \multirow{2}{*}{$\begin{array}{l}\text { PELLET DENSITY/ } \\
\text { FUEL TYPE } \\
\end{array}$} & \multirow{2}{*}{$\begin{array}{c}\text { SINTERING } \\
\text { ATMOSPHERE } \\
\end{array}$} & \multirow{2}{*}{$\begin{array}{c}\text { STORAGE } \\
\text { ATMOSPHERE }\end{array}$} & \multirow{2}{*}{$\begin{array}{c}\text { OUTGASSED } \\
\text { AFTER SINTERING } \\
\end{array}$} & \multirow{2}{*}{$\begin{array}{l}\text { TOTAL AMOUNT Of } \\
\text { GAS REEEASED DURING } \\
\text { FINAL OUTTAS } \\
\text { (cclg) } \\
\end{array}$} & \multirow{2}{*}{$\begin{array}{c}\text { OUTGAS } \\
\text { TEMPERATURE } \\
\left({ }^{\circ} \text { C) }\right. \\
\end{array}$} & \multicolumn{7}{|c|}{$\begin{array}{c}\text { COMPOSITION OF RELEASED GAS } \\
\text { (MOLAR } \%)\end{array}$} \\
\hline & & & & & & & & $\mathrm{N}_{2}$ & $0_{2}$ & $\mathrm{H}_{2} \mathrm{O}$ & $\mathrm{H}_{2}$ & co & $\mathrm{CO}_{2}$ & $\mathrm{He}$ \\
\hline GEAP $-4314^{(4)}$ & 8 & $94 \% \mathrm{TD} / \mathrm{UO}_{2}$ & $\mathrm{H}_{2}$ & $\mathrm{H}_{\mathrm{e}}$ & No & $\begin{array}{l}0.007-0.01 \mathrm{ccc} / \mathrm{g} \\
\text { AVG } \sim 0.0085 \mathrm{cc} / \mathrm{g}\end{array}$ & $1500-1700$ & $\begin{array}{c}1-15 \% \\
A V G \approx 2.2 \%\end{array}$ & $1 \%$ & $\begin{array}{l}\text { ND - } 15 \% \\
\text { AVG } \approx 6 \%\end{array}$ & $\begin{array}{l}16-39 \% \\
A \vee G \approx 26.5 \%\end{array}$ & $\begin{array}{l}14-36 \% \\
A V G \sim 24 \%\end{array}$ & $\begin{array}{c}1-7 \% \\
\operatorname{AVG} \approx 2.5 \%\end{array}$ & $\begin{array}{l}33-59 \% \\
\text { AVG } \approx 43 \%\end{array}$ \\
\hline AECL $-4063^{(6)}$ & 12 & $97.5 \% \mathrm{TD}^{\mathrm{U}} \mathrm{OO}_{2}$ & $\mathrm{H}_{2}$ & AIR & No & $\begin{array}{l}0.008-0.054 \mathrm{cc} / \mathrm{g} \\
\text { AVG } \sim 0.0256 \mathrm{cclg}\end{array}$ & $800-1100$ & $\begin{array}{l}\text { ND }-47 \% \\
\text { AVG } \approx 6 \% \%\end{array}$ & $\begin{array}{l}\text { ND }-15 \% \\
\text { AVG } \approx 1.6 \%\end{array}$ & $\begin{array}{l}0.5-18 \% \\
A V G \sim 3.6 \%\end{array}$ & $\begin{array}{l}40-90 \% \\
\operatorname{AvG} \approx 73 \%\end{array}$ & $\begin{array}{l}1-20 \% \\
A V G \approx 8.5 \%\end{array}$ & $\begin{array}{l}1-28 \% \\
A \vee G \approx 4.5 \%\end{array}$ & ND \\
\hline NUCL. SCI. ENG. $\left(1 \pi^{(7)}\right.$ & $\begin{array}{l}10 \text { PELLETS OUTGASSED } \\
\text { TOGETHER }\end{array}$ & $\mathrm{NG}^{\prime} \mathrm{UO}_{2}$ & $\mathrm{H}_{2}$ & $\begin{array}{c}\text { AIR } \\
\text { (FOR } 6 \text { MONTHS) }\end{array}$ & No & $0.054 \mathrm{ccc} / \mathrm{g}$ & 240 & $39 \%$ & $3.5 \%$ & $53 \%$ & $003 \%$ & NA & $\mathrm{NA}$ & NA \\
\hline NUCL. SCI. ENG. $(11)^{(7)}$ & $\begin{array}{l}10 \text { PELLETS OUTGASSED } \\
\text { TOGETHER }\end{array}$ & $\mathrm{NG}^{\mathrm{N}} \mathrm{UO}_{2}$ & $\begin{array}{l}\text { CRACKED } \\
\text { AMMONIA }\end{array}$ & $\begin{array}{c}\text { AIR } \\
\text { (FOR } 6 \text { MONTHS) }\end{array}$ & No & $0.072 \mathrm{cclg}$ & 240 & $78 \%$ & $21 \%$ & 1 & ND & NA & $\mathrm{NA}$ & $\mathrm{NA}$ \\
\hline WHAN-SA-77 ${ }^{(8)}$ & $\begin{array}{l}11 \\
\text { IONLY I ANALYSED FOR } \\
\text { GAS COMPOSIIION) }\end{array}$ & $88-92 \%$ TD/MO & $\mathrm{Ar}-8 \% \mathrm{H}_{2}$ & NOT STORED & YES & $\begin{array}{l}0.007-0.038 \mathrm{cc} / \mathrm{g} \\
\text { AVG } \sim 0.025 \mathrm{cclg} / \mathrm{g}\end{array}$ & 1600 & $\mathrm{NA}$ & NA & NA & $30-50 \%$ & $70-50 \%$ & NA & NA \\
\hline WHAN-SA-77 & 5 & 88 - 90\% TD/MO & $\mathrm{AR}-8 \% \mathrm{H}_{2}$ & $\begin{array}{l}\text { STORED INA N } V_{2} \\
\text { ATMOSPHERE FOR IA } \\
\text { DAYS AFTER INITIAL } \\
\text { OUTGASSING }\end{array}$ & YES & $\begin{array}{l}0.025-0.079 \mathrm{cclg} \\
\mathrm{AVG} \sim 0.050 \mathrm{cclg} / \mathrm{g}\end{array}$ & 1600 & NG & NG & NG & $30-50 \%$ & $70-50 \%$ & NG & NG \\
\hline WHAN-SA-77 & 3 & 89 - 91\% TD/MO & $\mathrm{AR}-8 \% \mathrm{H}_{2}$ & & No & $\begin{array}{l}0.30-0.45 \mathrm{cclg} / \mathrm{g} \\
\text { AVG } \sim 0.37 \mathrm{cclg} / \mathrm{g}\end{array}$ & 1600 & NG & NG & NG & $90 \%$ & NG & NG & NG \\
\hline$\left(A-5108^{(9)}\right.$ & $\begin{array}{c}3 \\
\text { (ANALYSIS FOR GAS } \\
\text { COMPOSITION) }\end{array}$ & NG/MO & $\mathrm{Ar}-8 \% \mathrm{H}_{2}$ & NG & No & $\begin{array}{l}0.022-0.059 \mathrm{cclg} \\
\text { AV }, \sim 0.037 \mathrm{cclg} / \mathrm{g}\end{array}$ & 1800 & $3.4 \%$ & $1 \%$ & NA & $23 \%$ & $73 \%$ & $1 \%$ & $1 \%$ \\
\hline
\end{tabular}

ND - BeLoW DeteCtABLE LIMIT

NA - GAS CONSTITUENT NOT ANALYSED FOR

NG - NOT GIVEN, BUT WERE SAID TO BE MINOR CONTRIBUTORS

MO - MIXED OXIDE, $\mathrm{UO}_{2}-\mathrm{PUO}_{2}$ 
that hydrogen was still the major gas to be released (a factor of 10 hiqher than deuterium) indicating that the majority of hydroyen is not picked up) in the sintering operation and is most likely from moisture adsorbed after sintering. Denovan et al. also showed that there is a rapid adsorption of both $\mathrm{D}_{2} \mathrm{O}$ and moisture when exposed to a relative hunidity of either $40^{\circ} \mathrm{O}_{2} \mathrm{O}$ or moisture.

Mixed oxide fuel cooled in an inert atmosphere after sintering releases primarily carbon monoxide (50 to $70 \%$ ) and hydrogen (30 to $50 \%$ ) with a minor amount of nitrogen $(23 \%)$. The release of carbon monoxide is attributed to carbon impurities within the fuel while the hydrogen is probably again due to moisture.

Carlson ${ }^{(8)}$ has demonstrated that pellets with densities less than $92: "$ of theoretical density (TD) pick up increasingly more gas with decreasing density. These observations are attributed to the increase in open porosity for densities below 92\% TD. Since present commercial LWR fuels typically have densities $>92 \%$ TD, only those data in this density range will be referred to when possible.

The effect of the pellet sintering atmosphere on the composition of gaseous impurities released can be $i l l$ lustrated by comparing $\mathrm{UO}_{2}$ fuel sintered in hydrogen with $\mathrm{UO}_{2}$ sintered in cracked ammonia atmosphere $\left(\mathrm{NH}_{3}\right)$. There is a fair amount of outgassing data for $\mathrm{UO}_{2}$ sintered in hydrogen which shows hydrogen or moisture as the primary adsorbed gases. However, Ferrari ${ }^{(7)}$ has provided the only available outgassing data for $\mathrm{UO}_{2}$ pellets sintered in a cracked ammonia $\left(\mathrm{NH}_{3}\right)$ atmosphere. His results, which were obtained on a batch of eight pellets of unknown density and at a relatively low outgassing temperature, indicated that nitrogen (78\%) is the primary gas released with oxygen making up the balance. The lack of moisture or hydrogen along with the large amount of gas released $\left(0.072 \mathrm{~cm}^{3} / \mathrm{g}\right)$ at the low outgassing temperature of $240^{\circ} \mathrm{C}$ is somewhat surprising. Ferrarj $(7)$ also reported data for a batch of hydrogen-sintered pellets outgassed at $240^{\circ} \mathrm{C}$ that showed a large amount of gas release $\left(0.054 \mathrm{~cm}^{3} / \mathrm{g}\right)$. These gas releases are not consistent with other outgassing data at this temperature. For example, Denovan et al. (6) have performed outgassings at several temperature 
intervals and found that not more than $0.009 \mathrm{~cm}^{3} / \mathrm{g}$ of gas is released from hydrogen-sintered $\mathrm{UO}_{2}$ fuel when heated between 190 and $240^{\circ} \mathrm{C}$. The large amount of gas found in Ferrari's pellets may be due to the long period of time ( $\sim 6$ months) the pellets were exposed to air prior to being outgassed.

The effect of storage atmosphere on the pickup of gaseous impurities by the pellets is best illustrated by a comparison of data from Denovan et a1. (6) and Spalaris and Megerth. (4) Denovan stored his pellets in air and from 12 individual outgassings obtained an average $0.026 \mathrm{~cm}^{3} / \mathrm{g}$ of gas with hydrogen and moisture making up three-fourths of the total, carbon monoxide and carbon dioxide comprising 13\%, and nitrogen only 6\%. Spalaris and Megerth stored their pellets in helium and from eight individual outgassings obtained an average $0.0085 \mathrm{~cm}^{3} / \mathrm{g}$ of gas with helium comprising $43 \%$ of the total, hydrogen and moisture 33\%, carbon monoxide and carbon dioxide $27 \%$, and nitrogen only $2 \%$. From these results it appears that the storage of hydrogen sintered pellets in an inert atmosphere significantly reduces the amount of adsorbed gas pickup of moisture and nitrogen. There is little effect on the amount of carbon monoxide and carbon dioxide. This is understandable because they are probably caused by carbon impurities within the fuel and thus are not affected by storage atmosphere.

Vacuum outgassing of oxide fuel is an effective means of reducing the amount of gaseous impurities retained within the fuel. Denovan et al. have shown that a previous outgassing can reduce the amount of adsorbed water on the fuel surface by 30 to $50 \%$ and five successive outgassings will reduce the surface adsorption capacity by a factor of 4 . Carlson (8) has performed vacuum outgassings on mixed oxide fuel peliets at 850 to $1000^{\circ} \mathrm{C}$ followed by a subsequent outgassing at $1600^{\circ} \mathrm{C}$. The 850 to $1000^{\circ} \mathrm{C}$ outgassings resulted in more than an order of magnitude reduction in gaseous impurities. However, when pellets were outgassed at $1000^{\circ} \mathrm{C}$ and stored in dry nitrogen, they showed a rapid initial uptake of adsorbed gas within 7 days which was double the amount of gas present immediately after the $1000^{\circ} \mathrm{C}$ outgassing. This amount remained approximately constant up to 90 days further exposure in the nitrogen, and is still a factor of 7 
decrease in gaseous impurity content in comparison to the initial amount present in the as-sintered pellots. Consequently, we conclude that outgassing in a vacuum and subsequent storage in a dry atmosphere will reduce the gaseous impurity content of as-sintered oxide fuel.

The amount of gas (average $0.37 \mathrm{~cm}^{3} / \mathrm{g}$ ) present in the as-sintered mixed oxide pellets used by Carlson was a factor of 10 higher than the amount of gas Vance et a1. (9) obtained from as-sintered pel lets outgassed at $1800^{\circ} \mathrm{C}$ although the gas compositions were similar. The disparity could be due to differences in the atmospheres the pellets were cooled in after sintering. Chidester $(10)$ has found that cooling hypostoichiometric mixedoxide pellets in the $\mathrm{Ar}-\mathrm{H}_{2}$ sintering atmosphere results in a pickup of $0.28 \mathrm{~cm}^{3} / \mathrm{g}$ of hydrogen, while cooling in a vacuum or inert atmosphere of Ar resulted in a pickup of less than $0.05 \mathrm{~cm}^{3} / \mathrm{g}$. Shalek et a1. (11) has reported that increases in substoichiometry for mixed-oxide pellets cooled in $\mathrm{Ar}-5 \% \mathrm{H}_{2}$ results in larger total gas content. He has also reported that increased open porosity leads to larger gas contents.

The data in Table 1 is obviously very sparse (especially for $\mathrm{UO}_{2}$ sintered in cracked ammonia) and sometimes contradictory. However, we have made some conclusions on the release of gaseous impurities from $\mathrm{UO}_{2}$ sintere: in hydrogen and cracked ammonia, and from $\mathrm{UO}_{2}-\mathrm{PuO}_{2}$ sintered in argon-8\% hydrogen.

From Denovan et a1. (6) we conclude that, on the average, $20.026 \mathrm{~cm}^{3} / \mathrm{g}$ of gaseous impurities with $75 \%$ hydrogen, $13 \%$ carbon monoxide and carbon dioxide, and $6 \%$ nitrogen could be expected to be released from hydrogen sintered $\mathrm{UO}_{2}$ that was stored in air. The amount of gas apparently retained between individual pellets varies considerably even for pellets within the same processing batch (up to $\pm 50 \%$ ) so that the average release quoted here may have a large amount of variance associated with it. The amount of gas adsorbed can be reduced by approximately a factor of 3 if the pellets are stored in an inert atmosphere immediately after outgassing based on Spalaris and Megerth's ${ }^{(4)}$ data. The data from hydrogen sintered $\mathrm{UO}_{2}$ represents the largest amount of data available (20 outgassings from References 4 and 6) 
and appears to be consistent; however, further investigations should be performed due to the large amount of variance among the data.

Ferrari ${ }^{(7)}$ has performed one outgassing on $10 \mathrm{UO}_{2}$ pellets sintered in cracked ammonia and found $0.072 \mathrm{~cm}^{3} / \mathrm{g}$ of gaseous impurities with 78 nitrogen and $21 \%$ oxygen. However, it is not recommended that this data be used as an accurate representation of fuel sintered in cracked ammonia because a relatively low outgassing temperature was used. A similar outgassing by Ferrari on hydrogen-sintered pellets gave an unexpected large amount of qas when compared to other data at a similar outqassing temperature. As shown earlier, the effect of gaseous impurities released from fuel sintered in cracked ammonia may be significant in an operating fuel rod if larger amounts of nitrogen are released. As will be shown in Section 4.0, an amount of nitrogen equal to $0.026 \mathrm{~cm}^{3} / \mathrm{g}$ can take several days to react with the cladding.

The quantity of indigenous gases from mixed-oxide fuel appears to be dependent on several factors: cooling atmosphere following sintering, stoichiometry, and open porosity. If the mixed-oxide pellets are cooled in a vacuum or inert atmosphere and the stoichiometry is kept between 1.97 to 2.00 , the release of indigenous gases is below $0.05 \mathrm{~cm}^{3} / \mathrm{g}$, which is similar to releases from $\mathrm{UO}_{2}$ fuel. It should be pointed out the conclusions here are tentative because they are based on data from LMFBR mixed-oxide fuel rather than the recycled mixed-oxide fuel proposed for LWRs. The LWR mixed-oxide fuel is higher in density (will probably result in less gaseous impurities) and lower in $\mathrm{PuO}_{2}$ content (effect on gaseous impurities is unknown) than the LMFBR fuel. Further investigation is needed to provide more reliable data for recycled mixed-oxide fuel. 


\subsection{GASEOUS IMPURITIES - ZIRCALOY CLAD REACTION KINETICS}

The purpose of this section is to determine the amount of time it takes for typical amounts of indigenous gases within a commercial LWR fuel element to react with the Zircaloy clad under in-reactor operating conditions. In addition to the calculation of reaction times, we will recommend and discuss the reaction rate constants and the appropriate rate equations for each of the indigenous gases used in the calculation of reaction times. The reaction rate constants, temperatures, rate equations, and references from which they are based are summarized in Table 2. In Section 3.0 we have estimated the amount and composition of gaseous impurities released from $\mathrm{UO}_{2}$ fuel sintered in either hydrogen or cracked ammonia and $\mathrm{UO}_{2}-\mathrm{PuO}_{2}$ fuel sintered in argon-hydrogen.

It should be pointed out that the reaction times calculated here for a commercial LWR fuel element are in many cases only a gross estimate which is due to the Targe uncertainties present in the amount and composition of released gases, uncertainties in reaction rates and the lack of quantitative data to evaluate the effect each gas has on the reaction rates of the others. The following analysis of the reaction times may be somewhat conservative, in terms of pin pressures and gas composition, because when thare are discrepancies in e'norimental results we have generally selected the more conservative results to perform the calculations.

The major reactive gaseous impurities released by oxide fuel have been identified as hydrogen, carbon monoxide, carbon dioxide, nitrogen, moisture and oxygen. The reaction kinetics of these gases with $\mathrm{Zr}-2$ and $\mathrm{Zr}-4$ presently used as cladding in LWRs is very sparse which has made it necessary in some cases to use reaction rates for unalloyed zirconium. A comparison of the Zircaloy data points found for hydrogen, carbon monoxide and carbon dioxide reaction rates and those obtained from unalloyed zirconium show little or no differences (in comparison to the scatter in the 
TABLE 2. Summary of Reaction Rate Data

\begin{tabular}{|c|c|c|c|c|c|}
\hline REFERENCE & GAS CONSTITUENT & MATERIAL USED & $\begin{array}{l}\text { APPLICABLE REACTION } \\
\text { RATE EQUATION }\end{array}$ & $\begin{array}{l}\text { ACTIVATION ENERGY } \\
\text { Of REACTION (kcal/mole) }\end{array}$ & $\begin{array}{l}\text { REACTION RATE } \\
\text { CONSTANT AT } 300^{\circ} \mathrm{C} \\
\end{array}$ \\
\hline 12 & HYDROGEN & ABRADED ZIRCONIUM & $W=k t^{*}$ & NG & $1.9 \times 10^{-2} \mu \mathrm{g} / \mathrm{sec}$ \\
\hline 14 & MOISTURE & ABRADED $2 r-2$ & $w=k^{1 / 3} t^{0.39}$ & 29.7 & $1.7\left(\mu \mathrm{g} / \mathrm{cm}^{2}\right)^{3} / \mathrm{sec}$ \\
\hline 18 & OXYGEN & ABRADED $\mathrm{Zr}-2$ & $w^{2}=k t$ & $22.2^{+}$ & $\left.1 \times 10^{-2} \mathrm{ug} / \mathrm{cm}^{2}\right)^{2} / \mathrm{sec}$ \\
\hline 12 & NITROGEN & ABRADED ZIRCONIUM & $w^{2}-k t$ & $\begin{array}{l}\text { INDEPENDENT OF } \\
\text { TEMPERATURE } \\
\text { BELOW } 500^{\circ} \mathrm{C}\end{array}$ & $2 \times 10^{-3}\left(\mathrm{ug} / \mathrm{cm}^{2}\right)^{2} / \mathrm{sec}$ \\
\hline $19-22$ & CARBON MONOXIDE & CHEMICAL POLISHED & $W=k t+C$ & 6.77 & $3.3 \times 10^{-3} \mathrm{\mu g} / \mathrm{cm}^{2} / \mathrm{sec}$ \\
\hline & CARBON DIOXIDE & $\mathrm{Zr}-2 \mathrm{ZIRCONIUM}$ & $W=k t$ & & \\
\hline
\end{tabular}

* REACTION IS LINEAR FOR TIMES < 20 MINUTES AND THEN BECOMES PARABOLIC FOR TIMES > 20 MINUTES

+ BETWEEN 300 TO $400^{\circ} \mathrm{C}$ 
data) in the temperature range of interest. Thus the use of reaction rates for unalloyed zirconium is a good approximation for the gases and temperatures considered in this report.

The reaction rates for the above gaseous impurities are often determined from abraded zirconium or Zircaloy. Thus, the data may not be applicable for the reaction with the inner cladding of a fuel rod because the abraded surface may have larger surface area or thinned oxide surface that will contribute to a different reaction rate. Gulbransen and Andrews have shown results (Figure 2) that indicate the oxidation rate constant for unabraded Zircaloy is approximately $1 / 3$ of the abraded reaction rate constant (i.e., a factor of 3 longer reaction times). However, Porte et al. (3) performed a similar experiment on relatively large parallelepiped-shaped samples in the same temperature range and found the surface condition has little effect on the oxidation rates. Due to the conflicting evidence of these two experiments we cannot come to any definitive conclusion as to surface effects. However, to bound possible clad surface effects and other uncertainties with the data, we have performed two calculations estimating indigenous gas reaction times. The first uses reaction rates experimentally determined from abraded specimens. The reaction times based on these rates may be faster than experienced in reality, depending on surface effects that could reduce reaction rates. In the second calculation we have reduced the abraded reaction rates by a factor of three to place a lower bound on the reaction times. From these two estimates we have examined their potential effect on fuel performance.

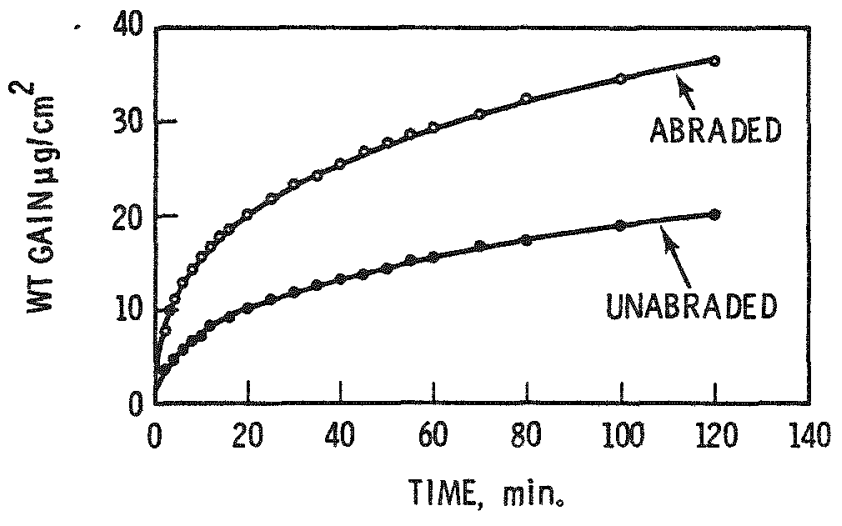

FIGURE 2. Reaction of Zirconium with Oxygen at $350^{\circ} \mathrm{C}$ 
The possible influence each of the gaseous impurities may have on the reaction of the other gases will be discussed and considered (when possible) in the following analysis.

The inner cladding temperatures in a typical BWR fuel rod generally vary between $280^{\circ} \mathrm{C}$, which is approximately the inlet temperature, to $360^{\circ} \mathrm{C}$ for a point on the cladding where the linear heat rating is $210 \mathrm{~kW} / \mathrm{ft}$. Inner cladding temperature in a PWR will be 10 to $25^{\circ} \mathrm{C}$ higher than for a BWR. In the following analysis we will use reaction rate kinetics that have been measured at or extrapolated to $300^{\circ} \mathrm{C}$.

As in the out-of-reactor outgassings, hydrogen gas can be a major constituent released within a commercial fuel rod if the adsorbed moisture is reduced to hydrogen by the fuel or its impurities. If we assume that the average amount of hydrogen $\left(0.019 \mathrm{~cm}^{3} / \mathrm{g}\right)^{(a)}$ found in outgassings of hydrogensintered $\mathrm{UO}_{2}$ is present within a typical BWR fuel rod (i.e., a rod having $4.3 \mathrm{~kg}$ of $\mathrm{UO}_{2}$ and cladding of $1.24-\mathrm{cm}$ ID and $400-\mathrm{cm}$ length), there will be $4.68 \mu \mathrm{g}$ of hydrogen per $\mathrm{cm}^{2}$ of cladding, as calculated below:

$$
\frac{\left(0.019 \mathrm{~cm}^{3} \mathrm{H}_{2} / \mathrm{g} \mathrm{UO}_{2}\right)\left(4.3 \times 10^{3} \mathrm{~g} \mathrm{UO}_{2}\right)}{2 \pi(1.24 \mathrm{~cm} / 2)(400 \mathrm{~cm})} \cdot\left[\frac{2 \mathrm{~g} \mathrm{H}_{2}}{\text { mole }} \cdot \frac{\text { mole }}{22.4 \times 10^{3} \mathrm{~cm}^{3} \mathrm{H}_{2}}\right]=\frac{4.68 \mathrm{\mu g} \mathrm{H}}{\mathrm{cm}^{2}}
$$

Using the linear reaction rate measured by Gulbransen and Andrews for abraded zirconium at $300^{\circ} \mathrm{C}$ and $20 \mathrm{~mm} \mathrm{Hg}$ pressure, we find that the hydrogen reacts within 4.1 min if no oxidants are present to keep a protective oxide film on the cladding. (The $20 \mathrm{~mm} \mathrm{Hg}$ pressure is a lower partial

(a) From Reference 6 in Table $1,73 \%$ of $0.026 \mathrm{~cm}^{3} / \mathrm{gm}$. Specifications for commercial fuel limit both hydrogen and water to values slightly below this value. 
pressure than expected from hydrogen release in a BWR fuel rod, but gas pressure has onty a small effect on reaction rates and may be neglected in this analysis.)

$$
t=\left(\frac{4.68 \times 10^{-6} \mathrm{~g} / \mathrm{cm}^{2}}{1.9 \times 10^{-8} \mathrm{~g} / \mathrm{cm}^{2} / \mathrm{sec}}\right)\left(\frac{1}{60 \mathrm{sec} / \mathrm{min}}\right)
$$

The above situation is likely if the oxidants react with the fuel or its impurities before reacting with the cladding. However, the moisture within a commercial fuel rod may not all react with the fuel (or its impurities), as in the outgassings, but some may also react with the cladding. If we assume $0.019 \mathrm{~cm}^{3} / \mathrm{g}$ of moisture is present within the fue 1 and $50 \%$ reacts with the cladding, there will be approximately $18.7 \mu \mathrm{g}$ of oxidant (from the water vapor) per $\mathrm{cm}^{2}$ of cladding in a typical BWR fuel rod, as calculated below:

$\frac{\left(9.5 \times 10^{-3} \mathrm{~cm}^{3} \mathrm{H}_{2} \mathrm{O} / \mathrm{g} \mathrm{VO}_{2}\right)\left(4.3 \times 10^{3} \mathrm{~g} \mathrm{VO}_{2}\right)}{2 \pi(1.24 \mathrm{~cm} / 2)(400 \mathrm{~cm})} \cdot\left[\frac{16 \mathrm{~g} \mathrm{O}}{\mathrm{mole} \mathrm{H}_{2} \mathrm{O}} \cdot \frac{\mathrm{mole} \mathrm{H}_{2} \mathrm{O}}{22.4 \times 10^{3} \mathrm{~cm}^{3} \mathrm{H}_{2} \mathrm{O}}\right]=\frac{18.7 \mathrm{\mu g} \mathrm{O}}{\mathrm{cm}^{2}}$

Using the reaction rate equation measured by Mallet ${ }^{(14)}$

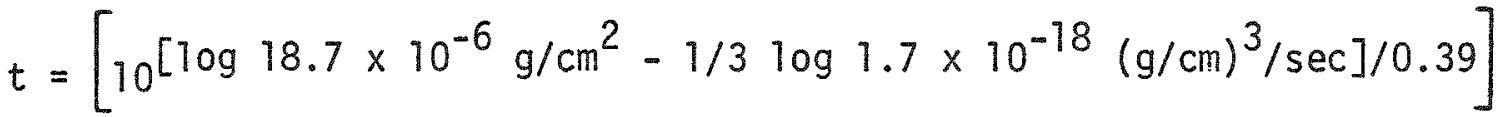

$$
\begin{aligned}
& {\left[\frac{1}{60 \mathrm{sec} / \mathrm{min}}\right]}
\end{aligned}
$$

for abraded zirconium in water vapor at $300^{\circ} \mathrm{C}$ and $33 \mathrm{~mm} \mathrm{Hg}$ pressure, we find that it takes only 19.4 min for this amount to react with the cladding by the following reaction:

$$
\mathrm{Zr}+2 \mathrm{H}_{2} \mathrm{O} \longrightarrow \mathrm{ZrO}_{2}+\mathrm{H}_{2}
$$

Decreasing the reaction by $1 / 3$, due to the possible differences in abraded and unabraded zirconium reaction rates, still results in a relatively fast reaction time of $\sim \mathrm{T} \mathrm{hr}$. An oxide thickness of $\sim 1200 \AA$ will be 
produced assuming the moisture reacts uniformly with the clad. Previous evidence has shown (15) that between 5 and $40 \%$ of the hydrogen produced wi11 be adsorbed by the cladding during the reaction. The reaction of the moisture with the cladding will help the cladding sustain a protective $\mathrm{ZrO}_{2}$ film which will prevent the majority of the hydrogen, and most likely other non-oxidant gases, from reacting with the cladding. However, once all of the moisture is consumed the protective oxide film cannot be sustained, and it will break down permitting the hydrogen and other gases to react with the cladding. Although we have assumed uniform reaction zones, for simplicity, hydride failures are often initiated by localized penetration of the protective oxide layer. Marshal1 ${ }^{(16)}$ has observed that the time for the breakdown of $\mathrm{ZrO}_{2}$ in hydrogen is dependent on both partial pressure and temperature (Table 3 ). The $\mathrm{ZrO}_{2}$ film on Marshall's samples was obtained by a chemical polish $\left(45 \% \mathrm{H}_{2} \mathrm{O}, 50 \% \mathrm{HNO}_{3}\right.$ and $\left.5 \% \mathrm{HF}\right)$ which typically produces a film thickness of 50 to $100 \mathrm{~A}$. This is somewhat thinner than the oxide film produced from the above reaction between the moisture and cladding. Also, the hydrogen pressures used by Marshall are lower than the partial pressure $(\sim 1.6 \mathrm{~atm})$ that would exist from $9.5 \times 10^{-3} \mathrm{~cm}^{3} \mathrm{H}_{2} / \mathrm{g} \mathrm{U0} \mathrm{O}_{2}$ being released within a BWR fuel rod with $47 \mathrm{~cm}^{3}$ void volume at the coolant temperature. Extrapolating Marshall's observed dependence of breakdown times to $1.6 \mathrm{~atm}$ at $300^{\circ} \mathrm{C}$ we estimate the breakdown time to be 275 min for a $\mathrm{ZrO}_{2}$ thickness of $275 \AA$. In order to extrapolate to the breakdown time for a $1200 \AA$ thick oxide we use Pemler's (17) results that the dissolution of $\mathrm{ZrO}_{2}$ depends on the square root of time. Consequently, the breakdown time of the $1200 \AA$ thick oxide wi11 be $\left(\frac{1200^{2}}{75}\right)(15 \mathrm{~min})\left(\frac{1}{1440 \mathrm{~min} / \text { day }}\right) \sim 2.7$ days. Due to the extrapolations made in this calculation it should only be considered a gross estimate until more relevant data become available.

TABLE 3. Time to Breakdown of $\mathrm{ZrO}_{2} \mathrm{Film}(16)$

\begin{tabular}{ccccc} 
Temperature & \multicolumn{3}{c}{ Hydrogen Pressure $(\mathrm{mm} \mathrm{Hg})$} \\
400 & $\frac{15}{10 \mathrm{Cr}}$ & $\frac{40 \text { to } 50}{1 / 2 \mathrm{hr}}$ & $\frac{100}{--}$ \\
350 & $40 \mathrm{ho} 60 \mathrm{hr}$ & $2 \mathrm{hr}$ & $-\infty$ \\
300 & & & & $100 \mathrm{hr}$
\end{tabular}


We can conclude from this analys is that nominal amounts of moisture and hydrogen within a commercial fuel rod will react very fast (between 4 min to 3 days, depending on the nature of the reaction) in comparison to the total irradiation time (>1000 days). Therefore, they may be neglected for most fuel performance calculations of pressure or gas composition. Additionally, a reactor often takes 1 to 2 days to reach full power, which is nearly equivalent to the maximum reaction time of these gases.

The oxygen reaction kinetics with zirconium are very similar to those exhibited above by moisture and, as is the case with moisture, it may a7so be very reactive with the fuel. Only trace amounts of oxygen are found when the $\mathrm{UO}_{2}$ is outgassed at temperatures $21000^{\circ} \mathrm{C}$, making it very difficult to estimate the amount adsorbed. However, Ferrarj ${ }^{(7)}$ observed a smal1 amount of oxygen (3.5\%) from $\mathrm{UO}_{2}$ sintered in hydrogen and a moderate amount $(23 \%)$ from fuel sintered in cracked ammonia when outgassed at $230^{\circ} \mathrm{C}$. If $0.005 \mathrm{~cm}^{3} / \mathrm{g}$ of oxygen were released from the fuel and if we ignore its possible reaction with the fuel, there will be approximately $19.7 \mu \mathrm{g}$ of oxygen per $\mathrm{cm}^{2}$ of cladding in a typical BWR fuel rod, as calculated below:

$$
\frac{\left(0.005 \mathrm{~cm}^{3} \mathrm{O}_{2} / \mathrm{g} \mathrm{UO}_{2}\right)\left(4.3 \times 10^{3} \mathrm{~g} \mathrm{UO}_{2}\right)}{2 \pi(1.24 \mathrm{~cm} / 2)(400 \mathrm{~cm})} \cdot\left[\frac{32 \mathrm{~g} \mathrm{O}}{\mathrm{mole}} \cdot \frac{\mathrm{mole}}{22.4 \times 10^{3} \cdot \mathrm{cm}^{3} \mathrm{O}_{2}}\right]=\frac{19.7 \mu \mathrm{g} \mathrm{O_{2 }}}{\mathrm{cm}^{2}}
$$

Using the parabolic reaction rate constant, $1 \times 10^{-14}\left(\mathrm{~g} / \mathrm{cm}^{2}\right)^{2} / \mathrm{sec}$, measured by Gulbransen and Andrews ${ }^{(18)}$ for abraded Zircaloy-2 at $300^{\circ} \mathrm{C}$ we find that it takes oniy $10.8 \mathrm{hr}$ for it to be consumed.

$$
t=\frac{\left(19.7 \times 10^{-6} \mathrm{~g} / \mathrm{cm}^{2}\right)^{2}}{1 \times 10^{-14}\left(\mathrm{~g} / \mathrm{cm}^{2}\right)^{2} / \mathrm{sec}} \frac{1}{3600 \mathrm{sec} / \mathrm{hr}}
$$

Even decreasing the reaction rate constant by $1 / 3$, due to possible differences in abraded and unabraded zirconium reaction rates, still results in a relatively fast reaction time of $32.4 \mathrm{hr}$ and thus may be neglected for most fuel performance calculations of pressure or gas composition (as was the case for moisture and hydrogen). 
Moisture and nitrogen may influence the oxygen reaction. Moisture will compete with the oxygen for the oxidation of the cladding; however, this effect will most likely be negligible because moisture is consumed relatively fast. There is evidence that the oxidation of zirconium in the presence of nitrogen proceeds faster than oxidation with pure oxygen, which supports our conclusions that oxygen will be consumed at a relatively fast rate.

It has been shown that the gaseous impurities of hydrogen, moisture, and oxygen are not expected to be present within a typical commercial fuel rod long enough to affect fuel performance; however, the slower reacting gases (nitrogen, carbon monoxide and carbon dioxide) may influence earlyin-life calculations.

Nitrogen gas reacts with zirconium to produce zirconium nitride:

$$
2 \mathrm{Zr}+\mathrm{N}_{2} \rightleftarrows 2 \mathrm{ZrN}
$$

Gulbransen and Andrews ${ }^{(12)}$ have determined the parabolic reaction rate constant, $K$, for abraded zirconium at $400^{\circ} \mathrm{C}$ and $500^{\circ} \mathrm{C}$ to be $\sim 2.0 \times 10^{-15}$ $\left(\mathrm{g} / \mathrm{cm}^{2}\right)^{2} / \mathrm{sec}$ (Figure 2). The time dependence of the reaction can be approximated by the parabolic relationship $W^{2}=k T$. These data (Figure 2) show the parabolic rate constant to be independent of temperature below $\sim 500^{\circ} \mathrm{C}$ which is somewhat surprising since the reaction rate constants for this reaction at higher temperatures follow an Arrehnius relationship. One might conciude that the oxygen impurities $(0.01 \%)$ within the nitrogen gas used in these reactions are reacting with the zirconium as has happened when less pure.nitrogen (0.3\% impurities) was used. (12) However, the reaction rate constant calculated is about a factor of 180 below that expected from a possible oxygen reaction at this temperature and also does not agree with the previous results using less pure nitrogen. Due to the lack of other data and the lack of evidence that an impurity in the gas is the cause for no temperature dependence in this temperature range, we have assumed the data to be valid. As shown earlier, the amount of nitrogen released from the fuel is very dependent on the sintering atmosphere. 


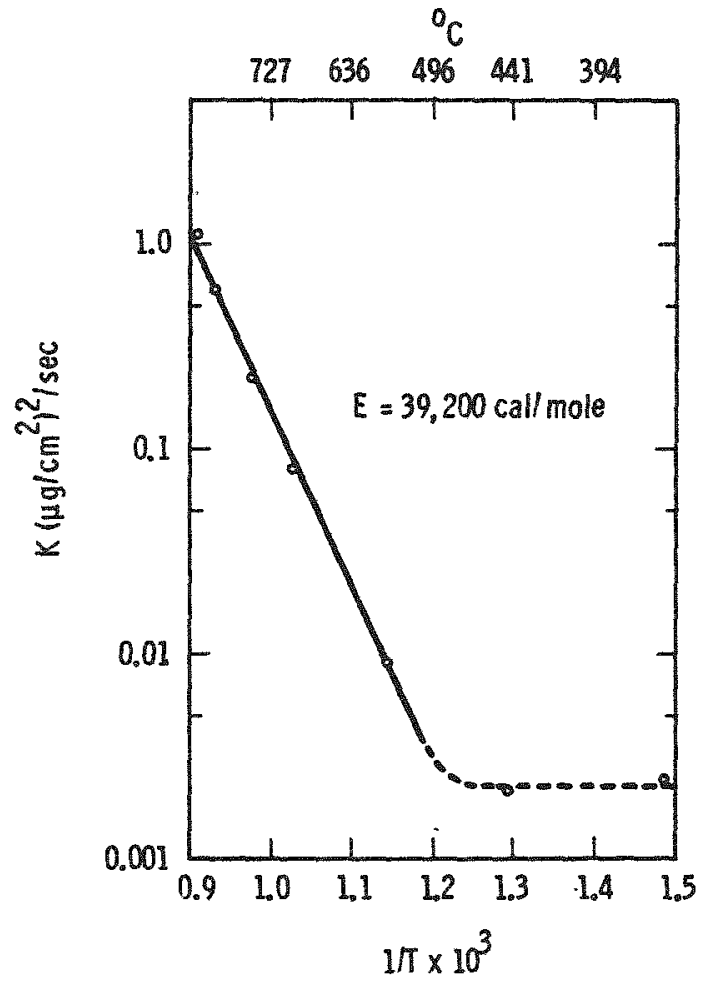

FIGURE 3. Reaction of $\mathrm{Zr}$ with $\mathrm{N}_{2}$

Consequently, we will compare nitrogen releases and reaction rates for a BWR fuel rod containing fuel sintered in either hydrogen or cracked ammonia. Gas released from fuel sintered in a hydrogen atmosphere has been shown to contain 2 to $6 \%$ nitrogen out of a total average release of $0.026 \mathrm{~cm}^{3} / \mathrm{g}$ (from Table 1 and Section 2 results) which gives $5.4 \mu \mathrm{g}$ of nitrogen per $\mathrm{cm}^{2}$ of cladding in a typical BWR fuel rod:

$\frac{(0.06)\left(0.026 \mathrm{~cm}^{3} / \mathrm{g} \mathrm{U0} 2\right)\left(4.3 \times 10^{3} \mathrm{~g} \mathrm{UO}_{2}\right)}{2 \pi(1.24 \mathrm{~cm} / 2)(400 \mathrm{~cm})} \cdot\left[\frac{28 \mathrm{~g} \mathrm{~N}_{2}}{\text { mole }} \cdot \frac{\text { mole }}{22.4 \times 10^{3} \mathrm{~cm}^{3}}\right]=\frac{5.4 \mathrm{ug} \mathrm{N}}{\mathrm{cm}^{2}}$ 
Using the parabolic rate constant measured by Gulbransen and Andrews the nitrogen is consumed within

$$
t=\frac{\left(5.4 \times 10^{-6} \mathrm{~g} / \mathrm{cm}^{2}\right)^{2}}{2 \times 10^{-15}\left(\mathrm{~g} / \mathrm{cm}^{2}\right)^{2} / \mathrm{sec}}\left(\frac{1}{3600 \mathrm{sec} / \mathrm{hr}}\right)=4.05 \mathrm{hr} .
$$

Decreasing the reaction constant by $1 / 3$ results in a reaction time of $12 \mathrm{hr}$. Non-oxidizing reactions such as between nitrogen and Zircaloy cladding may be delayed for up to 3 days due to the possible formation of a protective oxide film from the cladding reaction with moisture.

Fuel sintered in cracked ammonia appears to have nitrogen as its major gaseous impurity, and we11-characterized outgassing data for this fuel is almost nonexistent; however, as a gross estimate we will assume that $0.026 \mathrm{~cm}^{3} / \mathrm{g} \mathrm{UO}_{2}$ of nitrogen gas wi 17 be released. Using this value and the reaction rate constant and equation used previousiy, we can calculate the reaction time for this amount of nitrogen within a typical BWR fuel rod as 247 days. Decreasing the reaction rate constant by $1 / 3$ results in a reaction time of $\sim 740$ days. These reaction times for nitrogen should only be considered as very rough estimates. There are large uncertainties associated with both the nitrogen-Zircaloy reaction rate constant and the amount of nitrogen. Before a more reliable calculation can be made to predict the amount of nitrogen present, additional nitrogen-Zircaloy reaction rate experiments should be performed to confirm or replace the results of Gulbransen and Andrews as we11 as further outgassings on $\mathrm{UO}_{2}$ sintered in cracked ammonia.

Carbon dioxide and carbon monoxide react with zirconium to form an oxide and carbide as follows:

$$
\begin{aligned}
& 2 \mathrm{Zr}+\mathrm{CO}_{2} \rightleftarrows \mathrm{ZrO}_{2}+\mathrm{ZrC} \\
& 3 \mathrm{Zr}+2 \mathrm{CO} \rightleftarrows \mathrm{ZrO}_{2}+2 \mathrm{ZrC} .
\end{aligned}
$$

As observed previously, carbon monoxide is the most common of the two gases found within oxide fuels, especially mixed oxide fuel. 
Shannon (19-22) has measured both carbon monoxide and carbon dioxide reaction rates from 390 to $750^{\circ} \mathrm{C}$; however, he did not calculate a reaction rate constant nor develop an equation from which to predict the reaction dependence with time. In our analysis of these data we have determined a reaction rate constant and developed an equation to be used to predict the carbon monoxide reaction rate for the range of temperatures and times of interest.

Shannon's reaction rates for both carbon monoxide and carbon dioxide are significantly lower at low temperatures $\left(\leq 550^{\circ} \mathrm{C}\right)$ than previously observed values $(23,24)$ and he proposes that contaminates of oxygen and moisture in the carbon monoxide and carbon dioxide gases may have been the reason for the higher reaction rates measured previously. Shannon obtained Matheson chemically pure (CP) grade carbon monoxide and Matheson Coleman grade carbon dioxide. In addition both gases were further gettered by passing them over $1000^{\circ} \mathrm{C}$ graphite chips before use.

Shannon used both crystal bar zirconium and Zircaloy-2 in his measurements of reaction rates. Close inspection of this data (Figure 4) shows no apparent differences in reaction rates between these two materials nor between the carbon monoxide and carbon dioxide reaction rates. Consequently, the data from the four reaction combinations (i.e., $\mathrm{CO}+\mathrm{Zr}-2$, $\mathrm{CO}_{2}+\mathrm{Zr}-2, \mathrm{CO}+$ crystal bar, $\mathrm{CO}_{2}+$ crystal bar) were used to evaluate the reaction rate constants for these two gases and the Zircaloys.

The majority of Shannon's data at $600^{\circ} \mathrm{C}$ and below shows a linear dependence with time after an initial (1 to 2 days) nonlinear reaction rate so that the amount reacted can be approximated by the simple linear equation.

$$
W=k t+c
$$

where

$$
\begin{aligned}
& W=\text { the amount reacted in grams, } \\
& k=\text { the reaction rate constant, } \\
& t=\text { reaction time in seconds, } \\
& c=\text { a constant. }
\end{aligned}
$$




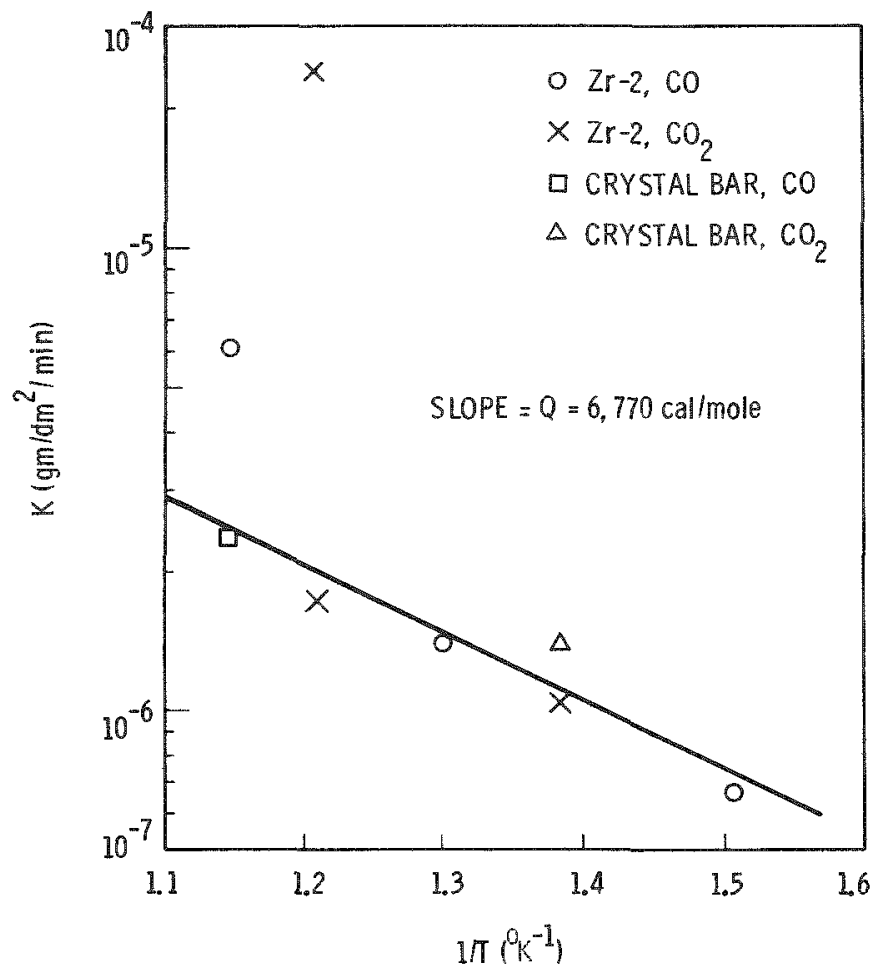

FIGURE 4. Reaction of $\mathrm{Zr}$ with $\mathrm{CO}$ and $\mathrm{CO}_{2}$

The higher temperatures $\left(700\right.$ to $\left.750^{\circ} \mathrm{C}\right)$ examined show an almost exponential increase in amount reacted after an initial incubation time. This "breakaway" type of corrosion in this temperature range was also observed by Gregg et al. (24) The "breakaway" corrosion in this temperature range does not agree with the linear dependence observed at the lower temperatures with which this study is concerned. Consequentiy, we did not use the 700 and $750^{\circ} \mathrm{C}$ data for our estimate of the reaction rate constants in the temperature range of interest, 300 to $400^{\circ} \mathrm{C}$.

Figure 4 shows an Arrhenius plot of the reaction rate data between 390 and $600^{\circ} \mathrm{C}$. The higher reaction rates displayed by the two data points at the higher temperatures $\left(550\right.$ and $600^{\circ} \mathrm{C}$ ) may be the result of the "breakaway" corrosion observed above $700^{\circ} \mathrm{C}$ or perhaps impurities in the gas used. We did not use these points in calculating the activation energy of 
$Q=6.77 \mathrm{kcal} / \mathrm{mole}$ from the slope. Using this activation energy, the linear reaction constant was determined to be $3.25 \times 10^{-9} \mathrm{~g} / \mathrm{cm}^{2} /$ min at $300^{\circ} \mathrm{C}$ and the constant $\mathrm{C}$ to be $4.2 \times 10^{-5} \mathrm{~g} / \mathrm{cm}^{2}$.

In our analysis of the reaction of carbon monoxide in a LWR fuel rod containing Pu-recycled fuel, we will assume that the recycled fuel will release a similar composition of gas as released by LMFBR mixed oxide fuel (50 to $70 \%$ carbon monoxide). We will futher assume that LWR recycled fuel will release the same amount of gas as the $\mathrm{UO}_{2}$ fuel of a similar density $\left(0.026 \mathrm{~cm}^{3} / \mathrm{g}\right)$. By combining the above reaction rate equation; $W=\left(3.25 \times 10^{-9} \mathrm{~g} / \mathrm{cm}^{2} / \min \right) t+4.2 \times 10^{-5} \mathrm{~g} / \mathrm{cm}^{2}$; the amount of gas released from recycled fuel as $0.026 \mathrm{~cm}^{3} / \mathrm{g}$; and that $70 \%$ of this gas is carbon monoxide, we can estimate the reaction time for this amount of carbon monoxide gas within a BWR fuel rod to be 273.4 days. As shown in Section 3.0, the balance of the gas released from recycled fuel $(230 \%)$ is moisture. This can compete with the carbon monoxide for oxidation of the cladding but as determined earlier for a BWR rod containing $\mathrm{UO}_{2}$ fuel, moisture is consumed quickly by the cladding and/or fuel. Thus the effect is negligible.

$\mathrm{UO}_{2}$ fuel sintered in hydrogen typically releases $2,10 \%$ carbon monoxide and $14 \%$ carbon dioxide out of a total average release of $0.026 \mathrm{~cm}^{3} / 9$ (from Table 1 and Section 2 results). The reaction times for these amounts of gas in a typical BWR fuel rod are $0,7.3$ days for carbon monoxide and 0.8 days for carbon dioxide. No data were available on the release of carbon monoxide and carbon dioxide from $\mathrm{UO}_{2}$ sintered in cracked ammonia; however, it is not expected to be significant.

As a check on the above analyses we have found an irradiation experiment in which gas constituents other than xenon and krypton were measured after irradiation. Freshley $(25,26)$ irradiated Zircaloy-clad mixed-oxide fuel to 3,220 MWd/MTM ( 60 fuel power days) and found only trace amounts of 
$\mathrm{N}_{2}\left(\cdot 10^{-4} \mathrm{~cm}^{3} / \mathrm{g}\right)$ with the remaining cases below the detectable 1 imits when the rods were punctured. Gas constituents have also been measured for Zircaloy clad fuel rods in Yankee Rowe. (27) A significant amount of nitrogen was found in some of these rods (up to 10 vol $\%$ ); however, oxygen was also present in almost a $4: 1$ ratio, indicating that an air leak might have existed in their gas collection system. If air had been present in the fuel rod during irradiation, the oxygen would almost certainly react with the cladding or fuel, leaving a very large nitrogen-to-oxygen ratio. 


\subsection{CONCLUSIONS}

Keeping the uncertainties of the reaction rates in mind we can make the following conclusions on the release of gaseous impurities from oxide fuel within a typical commercial LWR fuel rod:

- Previous experimental outgassings have shown that essentially all gaseous impurities will be released at temperatures above $1000^{\circ} \mathrm{C}$.

- Release rates are very fast. Nearly all of the total gas released occurs during the first $30 \mathrm{~min}$ or less when the fuel is heated above $1000^{\circ} \mathrm{C}$.

- Amount and composition of gaseous impurities varies with sintering and cooling atmosphere, fuel type, stoichiometry, open porosity, and storage atmosphere. The variance among pellets from the same processing batch is large (up to $150 \%$ ).

- The amount of indigenous gases within typical LWR-U02 fuel sintered in hydrogen does not exceed $0.05 \mathrm{~cm}^{3} / \mathrm{gm}$, and on the average is not above $0.03 \mathrm{~cm}^{3} / \mathrm{gm}$.

- Based on experiments from LMFBR mixed-oxide fuel a tentative conclusion is that LWR mixed oxides under controlled conditions will release a similar amount of gas as $\mathrm{UO}_{2}$.

- Very little or conflicting data exist for $\mathrm{UO}_{2}$ sintered in cracked ammonia.

- The primary constituents released from $\mathrm{UO}_{2}$ sintered in hydrogen are moisture and/or hydrogen.

- The primary constituents released from $\mathrm{UO}_{2}$ sintered in cracked ammonia appear to be nitrogen and oxygen.

- The primary constituents released from mixed-oxide fuel are hydrogen (from moisture) and carbon monoxide.

- Large uncertainties exist in reaction rate data for indigenous gases.

- Nominal amounts of hydrogen, moisture and oxygen will react with the fuel and/or cladding within 3 days or less. 
- Nitrogen $\left(0.026 \mathrm{~cm}^{3} / \mathrm{g}\right)$ released from $\mathrm{UO}_{2}$ sintered in cracked ammonia can take 50 to 140 days to react with the clad.

- $0.018 \mathrm{~cm}^{3} / \mathrm{g}$ of carbon monoxide released from Pu-recycle fuel sintered in argon-hydrogen will react with the clad within $\sim 13$ days.

- Only trace amounts of sorbed gas have been found in fuel rods irradiated for $n 60$ fuel power days. 


\subsection{RIIIRINCES}

1. M. J.F. Not7ey, R. Deshaies and J. R. Mac[wan, Measurements of the Fission Product Gas Pressures Developed in U0, Fuel Elements During Operation, AECL-2662, November 7966.

2. C. R. Hann, C. E. Beyer and L. F. Parchen, GAPCON-THERMAL-1:

A Computer Program for Calculating the Gap Conductance in Oxide Fuel Pins, BNWL-1778, September 1973.

3. C. E. Beyer, C. R. Hann, D. D. Lanning, F. E. Panisko and L. J. Parchen, GAPCON-THERMAL-2: A Computer Program for Calculating the Thermal Behavior of an Oxide FueT Rod, BNhL-1898, November 1975.

4. C. N. Spalaris and F. H. Magerth, Residual and Fission Gas Release from Uranium Dioxide, GEAP-4314, 1963.

5. V. J. Wheeler, "The Diffusion and Solubility of Hydrogen in Uranium Dioxide Single Crystals," J. Nucl. Matls., vol. 40, 1971.

6. A. 5. Denovan, R. W. Ashley and T. H. Longhurst, Internal Sources of Hydrogen in Unirradiated U0 2 Fuel Elements, AECL-4063, 0ctober 1971.

7. H. M. Ferrari, "Nitrogen Release from U0, Pellets at Elevated Temperatures," Nucl. Sci. and Eng., vol. 17, 1963.

3. M. C. J. Carlson, Water and Sorbed-Gas Content of Hypostoichiometric Mixed Oxide Fuel PelTets, WHAN-SA-77, September 1970.

9. D. E. Vance, M. E. Smith and G. E. Waterbury, Determination of Total Amount of Volatiles in Mixed-Oxide Reactor Fuel Pellets, LA-5108, February 1973.

10. K. M. Chidester, Control and Behavior of $0 / M$ and Offgas During Fabrication of Mixed Oxide (U0.75 Pu0.25) $0_{2-x}$ for HEDL Irradiation Testing, HEDL-TME 72-725, 0ctober 7972 .

11. P. D. Shalek, J. Y. Chang, P. M. Brench, and W. R. Jacoby, "Gas Adsorption in (U,Pu)O2 Fuel Pellets," Presented at 73rd Annual Meeting of American Ceramic Society, Chicago, April 26-29, 1971.

12. E. A. Gulbransen and K. F. Andrew, "Kinetics of the Reactions of Zirconium with $\mathrm{O}_{2}, \mathrm{~N}_{2}$ and $\mathrm{H}_{2}$, "Trans. AIME, vol. 185, p. 515.

13. H. A. Porte et al., Oxidation of Zirconium and Zirconium Alloys, ANL-6046, September 1959.

14. M. W. Mallet et al., "Reaction of Zirconium with Water Vapor at Subatmospheric Pressures," J. Electrochem. Soc., vol. 104, no. 6, June 1957. 
15. K. Videm, "Properties of Zirconium Base Cladding Materials, Corrosion and Hydrogen Pickup," Advanced Course on Limiting Aspects of Fuel Element Performance in Water Cooled Power Reactors, Kjeller, Norway. Institutt for Atomenergi, 1971.

16. R. P. Marsha11, "Absorption of Gaseous Hydrogen by Zircaloy-2," J.Less Common Metals, vol. 13, 1967.

17. J. P. Pemsler, Fundamental and Applied Research and Development in Metallurgy, Research on the Zirconium Alloys Corrosion in High Temperature, NMI-125T.

18. E. A. Gulbransen and K. F. Andrew, "Oxidation of Zircaloy-2 and $-3 A$ at 300 to $850^{\circ} \mathrm{C}, "$ Trans. AIME, vol. 212, p. 281.

19. D. W. Shannon, Quarterly Progress Report - Metallurgy Research Operation - October, November, December, 1962, HW-76228.

20. D. W. Shannon, Quarterly Progress Report - Metallurgy Research Operation - January, February, March, 1963, HW-77052.

21. D.W. Shannon, Quarterly Progress Report - Metallurgy Research Operation - Apri1, May, June, 1963, HW-77954.

22. D. W. Shannon, Quarterly Progress Report - Metallurgy Research Operation - August, September, October, 1963, HW-79345.

23. E. T. Hayes et a1., "Heat Resistance of Zirconium in Several Mediums," U.S. Bur. Mines Tech. Prog. Rept. 9, Contract Purchase Order No. (33-038) 50-1214E, December 21, 1951 .

24. S. J. Gregg et al., "Reaction of Zirconium with Carbon Dioxide at 55-750 ${ }^{\circ} \mathrm{C}, "$ Corrosion, vol. 17, pp. 91-94, December 1961.

25. M. D. Freshley, "Mixed-0xide Fuel Irradiations in the Plutonium Recycle Test Reactor," Nucl. Tech., vol. 15, August 1972.

26. D. G. Carter, T.B. Burley and M. D. Freshley, PRTR Fuel Evaluations, BNWL-1358.

27. J. B. Melehan, Yankee Core Evaluation Program Quarterly Progress Report for the Period Ending June 30, 1969, WCAP-3017-6090. 


\section{DISTRIBUTION}

No. of

Copies

OFFSITE

1

ERDA Chicago Patent Group

9800 Cass Avenue

Argonne, Illinois 60439

A. A. Churm

245 Basic Distribution Under NRC-1

61 Supplementary NRC-3 Distribution List

25 Nuclear Regulatory Commission, Division of Technical Review Chief, Core Performance Branch

2 ERDA Technical Information Center

U. S. Nuclear Regulatory Commission

Central Mail and Files

Washington, D. C. 20555

Mary Jinks

ONSITE

1

ERDA, Richland Operations office

H. E. Ransom

$40 \quad$ Battelle-Northwest
W. J. Bailey
C. E. Beyer
D. W. Brite
J. A. Christensen
N. C. Davis
M. D. Freshley
S. Goldsmith
C. R. Hann (10)
D. D. Lanning
R. R. Lewis

R. K. Marshall

R. P. Marshall

C. L. Mohr

P. J. Pankaskie

F. E. Panisko

L. J. Parchen

R. E. Williford

S. R. Wagoner

Technical Information Files (3)

Technical Publications 